
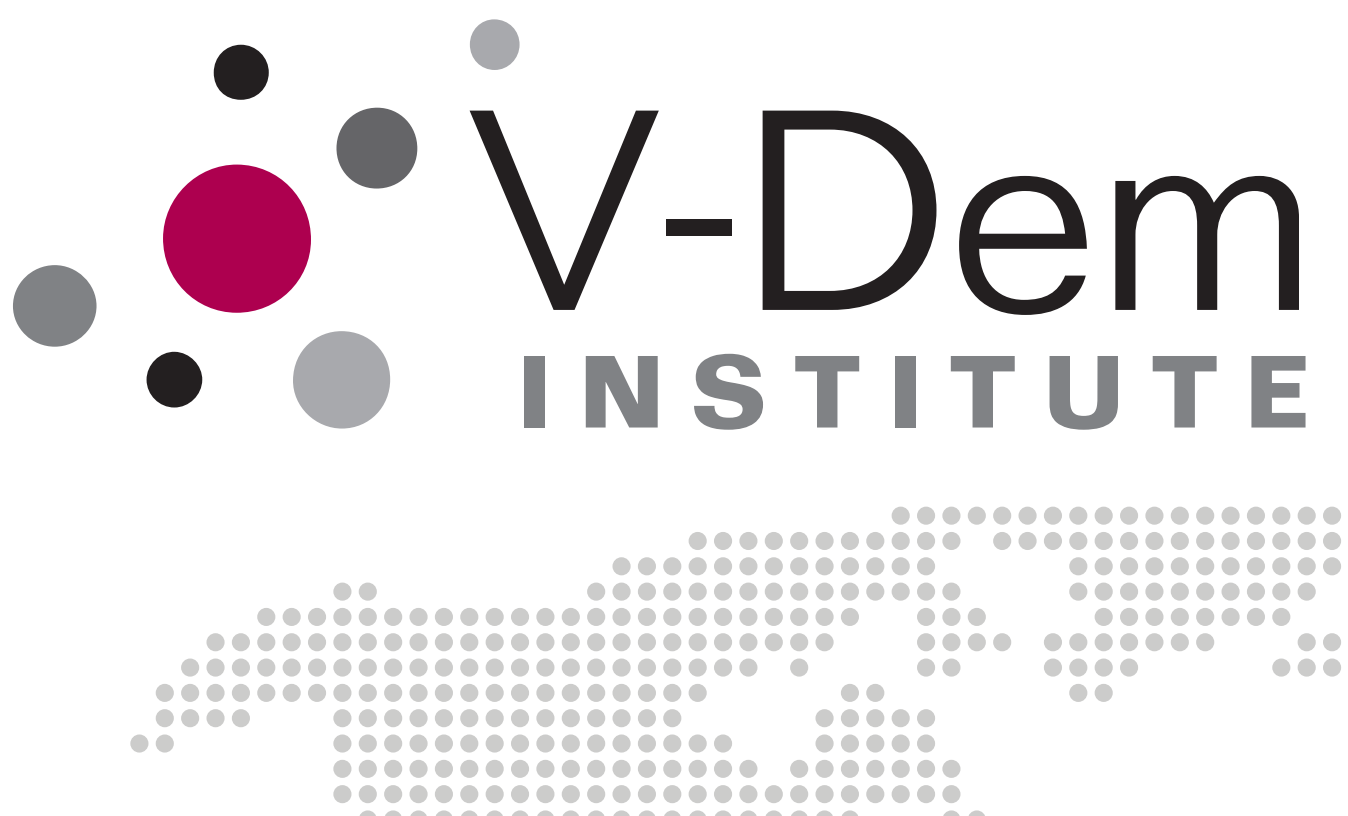

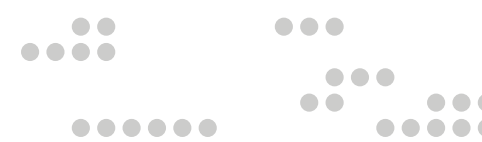

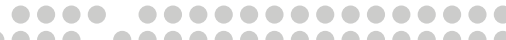
0000,000000000000000

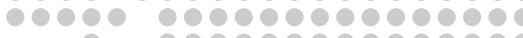
00

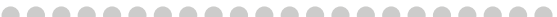

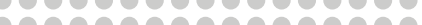

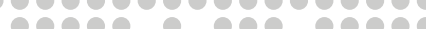

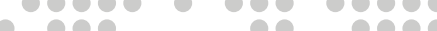
50

Do Political Finance Laws Reduce Corruption?

Calla Hummel, John Gerring and Thomas Burt

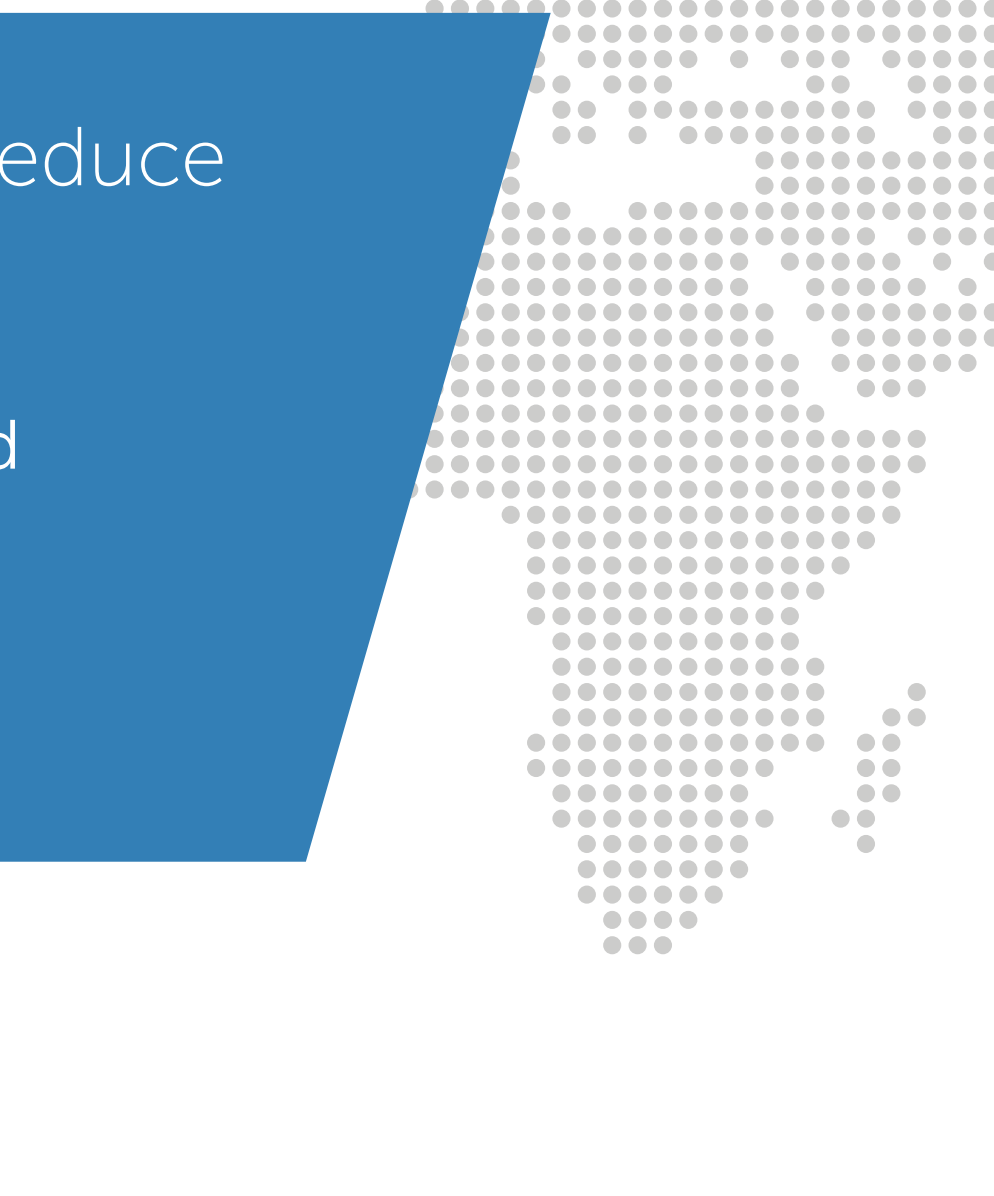

January 2018

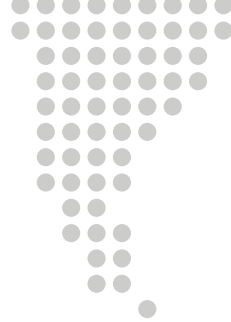

\section{Working Paper}

SERIES 2018:60

THE VARIETIES OF DEMOCRACY INSTITUTE
UNIVERSITY OF GOTHENBURG

DEPT OF POLITICAL SCIENCE 
Varieties of Democracy (V-Dem) is a new approach to conceptualization and measurement of democracy. It is co-hosted by the University of Gothenburg and University of Notre Dame. With a V-Dem Institute at University of Gothenburg with almost ten staff, and a project team across the world with four Principal Investigators, fifteen Project Managers (PMs), 30+ Regional Managers, 170 Country Coordinators, Research Assistants, and 2,500 Country Experts, the VDem project is one of the largest ever social science research-oriented data collection programs.

Please address comments and/or queries for information to:

V-Dem Institute

Department of Political Science

University of Gothenburg

Sprängkullsgatan 19, PO Box 711

SE 40530 Gothenburg

Sweden

E-mail: contact@v-dem.net

V-Dem Working Papers are available in electronic format at www.v-dem.net.

Copyright (C) 2018 by authors. All rights reserved. 


\title{
Do Political Finance Laws Reduce Corruption?*
}

\author{
Calla Hummel \\ Assistant Professor \\ Department of Political Science, University of Miami \\ John Gerring \\ Professor of Political Science \\ University of Texas at Austin
}

Thomas Burt

$\mathrm{PhD}$ candidate

Department of Government, University of Texas at Austin

\footnotetext{
* We gratefully acknowledge helpful comments from Kevin Casas-Zamora, Susan Scarrow, Agustín Vallejo, and the Political Science faculty workshop at the University of Miami. This research project was supported by Riksbankens Jubileumsfond, Grant M13-0559:1, PI: Staffan I. Lindberg, V-Dem Institute, University of Gothenburg, Sweden as well as by co-funding from the Vice-Chancellor's office, the Dean of the College of Social Sciences, and the Department of Political Science at University of Gothenburg. We performed simulations and other computational tasks using resources provided by the Notre Dame Center for Research Computing (CRC) through the High Performance Computing section and the Swedish National Infrastructure for Computing (SNIC) at the National Supercomputer Centre in Sweden, SNIC 2016/1-382 and 2017/1-68. We specifically acknowledge the assistance of In-Saeng Suh at CRC and Johan Raber at SNIC in facilitating our use of their respective systems.
} 


\section{Abstract}

Most countries regulate political finance and many offer public subsidies to political parties or candidates. Proponents of political finance regulations claim that public money reduces corruption in politics, while opponents worry that public subsidies have no impact on corruption and in some cases may add to it. Despite national-level debates and billions of taxpayer dollars, few studies test this relationship. We argue that political finance subsidies reduce corruption by reducing the influence of private money in politics and increasing legal and media sanctions for corrupt behavior. We evaluate the argument with an original dataset measuring political subsidies from 154 countries from 1900-2012, as well as disaggregated corruption measures from the Varieties of Democracy project. We also conduct a case study of political finance regulations in Paraguay. Our findings suggest that political finance subsidies reduce corruption, and particularly embezzlement, even in countries where regulations are unevenly implemented. 


\section{Introduction}

Nearly all countries now regulate political finance, and many offer subsidies for political parties or candidates. Public officials and scholars often claim that these interventions are necessary for the full achievement of representative democracy and good governance, and especially for combating political corruption (Bryan \& Baer 2005; Casas-Zamora 2005; Council of Europe 2003; United States Agency for International Development 2003).

Not everyone is optimistic. Skeptics point to the difficulty of implementing political finance regulations. Recurring scandals in some of the world's oldest and most generous political finance systems (e.g., Costa Rica, Germany, Israel, and France) seem to suggest that political finance has little impact, or perhaps even malevolent effects, on political behavior (CasasZamora 2005, p.39; Pinto-Duschinsky 2002, p.78; Williams 2000, p.1-8). Laws on the books are often weakly enforced, and even when they are enforced officials find ways to skirt regulations (Bryan \& Baer 2005, p.4; La Raja 2014a, p.714). Bryan and Baer (2005, p.4) suggest that unenforced political finance laws may encourage corruption while Mietzer (2016, p.102) argues that Indonesia's comprehensive but poorly implemented political finance laws hide endemic corruption. Calland (2016, p.152) finds that in South Africa subsidies put more money in corrupt elites' pockets and do not combat entrenched corruption. Roper (2002, p.186) suggests the same in Eastern Europe, with Romania as a case in point. Large-n crossnational analyses of the question discern no relationship between political finance subsidies and corruption (Evertsson 2013, p.83; Norris \& Abel van Es 2016, p.251).

Yet, evidence for these conclusions is selective. Evertsson (2013) and Norris and Abel van Es (2016) rely on cross-sectional analyses of a single year. Other studies focus on individual countries whose experiences may or may not be representative. Despite the importance of the issue and its prominence in popular discourse, the relationship between political finance and the quality of governance is under-theorized and has not been tested in a systematic fashion, perhaps because of the absence of suitable data (Butler 2010; Hopkin 2004; Samuels 2001).

In this study, we offer a straightforward argument for how and why campaign finance might impact political corruption, and what sort of corruption it might affect. To test the argument we construct a new dataset that measures public subsidies for parties and campaigns across most sovereign countries over the past century. This index is analyzed in a panel format using a measure of political corruption drawn from the Varieties of Democracy (V-Dem) project. We also trace the effects of political finance regulations through interviews with officials 
in Paraguay. Both quantitative and qualitative analyses suggest that political finance reform reduces political corruption across a range of government offices.

\section{Why Political Finance Might Matter}

The concept of political finance, as employed here, encompasses three elements: the legal and statutory regulation of money in politics (stipulating what practices are legal or illegal), government subsidies (in-kind or monetary) to support political parties and/or candidates for public office, and enforcement mechanisms to ensure that laws regulating behavior and subsidies are adhered to (Gokcekus \& Sonan 2016; Rose-Ackerman 1978). In principle, these factors vary independently: regulatory burdens may be strong, weak, or nonexistent; subsidies may be high, low, or nonexistent; enforcement may be strong, weak, or nonexistent. In practice, they tend to cohere (Evertsson 2013; Norris \& Abel van Es 2016). It is rare to find generous subsidies unaccompanied by extensive regulation, for example. Thus, we consider regulation, subsidies, and enforcement as components of a compound treatment with multiple levels.

Political corruption may be defined in a general fashion as the abuse of public office for private gain (Rose-Ackerman 1999, p.91). Typically, it involves the exchange of money or goods for political influence (Della Porta \& Vannucci 1999; Evertsson 2013). Sometimes, this agreement is explicit, a quid pro quo arrangement (e.g., a bribe) whereby a specific amount of money is transferred from a principal, $A$, to an agent, $B$, in exchange for $B$ 's action on an issue of concern to $A$ (Butler 2010, p.2; Gokcekus \& Sonan 2016; Williams 2000, p.1-2, 8). At other times, the exchange is implicit - a general understanding that $A$ would like $B$ to "do something about Policy X." We hold exchanges of this sort to be corrupt in the general sense of the term even if they break no existing law, as they involve what most would regard as an abuse of public office for private gain (McMenamin 2012, p.5). A public official may also embezzle state resources by illegally redirecting them to a campaign or into their own accounts.

In considering the impact of political finance reform on political corruption, we focus on the incentives facing politicians (those who hold public office or aspire to do so). We assume that politicians are motivated to win election, or reelection. We shall also assume that money plays an important role in winning elections in a context of multi-party competition (Samuels 2001) but that its marginal utility declines. A candidate's first dollar is worth much more than their last dollar (Abramowitz 1988; Gerber 1998; Green \& Krasno 1988; Levitt 1994).

Funding for election campaigns and party activities may be raised privately or publicly. Private money is susceptible to corrupt exchanges of money for influence, as defined above 
(Evertsson 2013; Gokcekus \& Sonan 2016). Public money is not. In making this assertion we are assuming that there are no corrupt bargains between the state, which provides funding, and the recipients of that funding. Note that in most instances subsidy disbursement formulas are very specific and therefore difficult to manipulate. Occasionally, election observers report that money arrives late or not at all (International Institute for Democracy and Electoral Assistance 2014, p.50), but this may be a result of laziness or ineptitude. We have not encountered allegations of corrupt bargains between parties (or candidates) and state agencies around subsidy disbursement.

It follows that to the extent that the role of private money in electoral campaigns is minimized, opportunities for corruption decrease. This may be accomplished by regulation, e.g., limiting the amount of money that candidates or parties can obtain from private sources, the kinds of donors that can contribute to campaigns, the amounts that each donor can contribute, and the transparency of these transactions (Fisher 2000, p.16; McSweeney 2000, p.39-40). It may also be accomplished by subsidizing campaigns with publicly provided funds or in-kind support (e.g., free access to broadcast media), which may replace or supplement money that officials raise privately (Bryan \& Baer 2005; Butler 2010; Williams 2000). If public money is provided on a supplementary basis, private money persists, to be sure. However, its importance in winning elections is mitigated by virtue of the declining marginal utility of money in a campaign (Gerber 1998). This, in turn, should mitigate the necessity of raising money and the degree to which politicians are beholden to donors.

We must also consider the possibility of legal sanction. All political finance laws are accompanied by an enforcement mechanism, intended to punish those who contravene the law (Evertsson 2013). Sanctions may include loss of office, fines, and/or incarceration. Of course, enforcement is uncertain, and it is difficult to gauge the strength and independence of the enforcement mechanism in a country (Pinto-Duschinsky 2002, p. 80). Nonetheless, the possibility of legal sanction is present when a political finance regime is in place and scarcely present when it is not. Insofar as corrupt exchanges violate political finance law, politicians who engage in such activities put themselves in legal jeopardy (Hopkin 2004). There are also secondary effects on a candidate's probability of winning election, given that the suggestion of scandal - even in the absence of a successful prosecution - may harm a candidacy or even end a political career (Balán 2011, p.459; Bassinger 2013, p.386; Hopkin 2004). ${ }^{1}$ For this reason, as well, we can anticipate that political finance laws impact the behavior of politicians.

\footnotetext{
${ }^{1}$ While some studies suggest that scandal has no impact on election outcomes (Vaishnav 2017), Bassinger (2013) finds that scandal-plagued House members lose votes and are much more likely than other incumbents to lose reelection, retire, or otherwise leave. In South America, Balán (2011) finds that party insiders leak scandals in an attempt to sabotage colleagues' careers and elevate one faction over another, suggesting that scandals do impact election outcomes.
} 
In summary, political finance laws attenuate the likelihood of a politician engaging in corrupt activity insofar as they (a) reduce the role of private money in campaign finance, (b) clarify the legal status of campaign finance activity (i.e., the line between what is legal and illegal), and (c) enhance the risk of discovery - and hence of negative publicity and possible legal sanction.

Political finance is only one source of political corruption. Natural resources, state monopolies, unstable economies, and many other factors can also fuel the abuse of public power for private gain (Rose-Ackerman 1999; Treisman 2000, 2007). Nonetheless, we posit that political finance is an important - and certainly understudied - factor. Moreover, as a policy tool, political finance reform is easier to implement than most other anti-corruption measures. (As we shall see, political parties usually welcome public funding, despite the strings attached to it.) Hence, our topic has important practical implications.

\section{Comparative Political Finance}

Britain and the United States began regulating political finance in the nineteenth century in an attempt to control rampant corruption around elections (Fisher 2000, p.16; La Raja 2008, p.1833; Rix 2008, p.65). Uruguay initiated the first political subsidy in 1928, legislating reimbursements for campaign expenses. Uruguayan politicians were concerned about the undue influence of donors and argued that subsidies would insulate parties from their influence and encourage broader representation and competition (Casas-Zamora 2005, p.95). Costa Rica introduced post-election reimbursements in 1956, becoming the second country to legislate campaign subsidies. According to Casas-Zamora (2005, p.73-74, 95-97), these pioneering subsidy schemes were uncontroversial because they regulated practices that citizens viewed with suspicion and introduced a measure of transparency through accounting requirements.

Later, when countries in Western Europe began to reform their political finance laws, these same arguments were recycled. ${ }^{2}$ Germany introduced funding for political parties in 1959 and political subsidies diffused to most western democracies in the following decades (Koß 2010; Scarrow 2004, p.661).

Countries transitioning to democracy in the 1980s and 1990s often adopted political finance regulations from established democracies in Latin America and Europe. For example, political finance reforms in Argentina and Mexico were patterned after Spain and Costa Rica, and were seen as a replacement for ad-hoc and informal transfers between state and party

\footnotetext{
2 Personal communication, Dr. Maria Gavouneli, GRECO delegate, January $2^{\text {nd }}, 2017$.
} 
(Instituto de Investigaciones Jurídicas 2011). Most post-communist countries crafted political finance systems modeled on European systems (Roper 2002, p.175). By the 2000s, world powers (especially the United States) and international organizations (e.g., the European Union and the Organization of American States) were pushing comprehensive political finance subsidies and regulations on the developing world (Council of Europe 2003; Koß 2010; United States Agency for International Development 2003).

At present, most democracies have political finance laws, and most of those laws include direct subsidies to parties or campaigns, as our dataset documents. Laws vary considerably across time and place (Butler 2010, International Institute for Democracy and Electoral Assistance, 2014). Most political finance systems mix public and private money (Williams 2000, p.8). The only country that prescribes sole reliance on public funding - i.e., the total elimination of nonpublic sources - is Bhutan, though Tunisia also banned private donations in the 2011 election (International Institute for Democracy and Electoral Assistance, p.49). A handful of mostly European countries rely primarily on public funding with some private donations (Butler 2010, p.7). In most countries, however, public subsidies comprise a minority of party and campaign budgets.

In addition to diffusion, it is worth noting several commonalities in the adoption of political finance reforms around the world. First, legislation is often introduced in the wake of major political scandals (Alexander \& Shiratori 1994, p. 3; Carlson 2016, p.103; Williams 2000, p.2). For example, after decades of limited and unenforced campaign finance regulations, the United States introduced campaign subsidies and comprehensive regulations in 1974 in response to the Watergate scandal (Briffault 2016, p.180; La Raja 2008, p.18-33; McSweeney 2000, p.40). Second, reformers often appeal to the importance of curbing special interests, leveling the playing field, and fighting corruption (Williams 2000). Third, public opinion surveys suggest that mass publics support political finance regulations like spending caps but are skeptical when politicians legislate subsidies that support their own campaigns (Avkiran, Kanol, \& Oliver 2016; Bryan \& Baer 2005, p.21; Primo \& Milyo 2006).

\subsection{Constructing a Dataset}

A great deal of activity has occurred over the past century in an attempt to reform systems of political finance. To capture this activity in a systematic fashion, we construct a dataset that covers the world at annual intervals from 1900 to the present.

Our effort builds upon the 2015 IDEA database of public finance laws, which tracks answers to a number of questions related to current public campaign finance for most countries 
that currently hold elections (International Institute for Democracy and Electoral Assistance 2017). Helpfully, IDEA publishes its sources - primarily, laws that are currently in force. Additional sources used in our coding include supranational reports, election observer reports, NGO reports, and academic articles. Of particular note are reports produced by the European Union's Group of States Against Corruption (GRECO), which provide detailed information on the history, provisions, implementation and public-private dimensions of campaign finance for about sixty countries. We also draw on two reports sponsored by the Organization of American States that cover Central and South America and the Caribbean. For African countries, we rely on the NGO Electoral Institute for Sustainable Democracy in Africa (EISA). We enlist election observer reports from the EU, the Commonwealth, the AU, EISA, and the Carter Center. Where laws or implementation were ambiguous, we sought advice from country experts.

With the assistance of these sources we coded relevant laws establishing different types of political finance regimes in 154 countries that held national elections between 1900 and 2012. (Countries that do not hold regular national elections are excluded from the dataset.) For further information on coding protocol and sources, the reader is referred to Appendix A. Detailed information on each country, including dates of adoption of major public finance initiatives and country-specific sources, are included in Appendix B.

In selecting variables to code, we lean primarily upon the provision of public subsidies for candidates and parties. Public subsidies are one of the strongest political finance interventions and also serve as a proxy for other regulatory actions that are harder to measure in a systematic fashion (Norris \& Abel van Es 2016, p.15). We are not aware of any public subsidy that is unaccompanied by additional regulatory measures.

Chosen variables measure: (1) whether a law sets out provisions for regular subsidies to party organizations, (2) whether this provision has been implemented, (3) whether a law sets out provisions for election campaign subsidies, (4) whether this provision has been implemented, and (5) whether a majority of political funds derives from (a) private or (b) public sources. The resulting dataset consists of five binary variables coded across 154 countries and 112 years, generating 11,409 country-year observations.

A principal component analysis demonstrates that a single dimension explains most of the variance $(72 \%)$. The first component also loads similarly on all five variables. This suggests that our five variables are capturing one underlying concept that can be meaningfully combined into a single political finance index (PFI). We form this index by addition because it is easy to interpret and to decompose. (Additive and principal components indices are highly correlated 
$(\mathrm{r}=0.99)$, and render similar results, as shown in Appendix $\mathrm{C})$. The resulting additive index ranges from 0 to 5 .

Using this index, we are able to visualize changes in political finance globally over time. Figure 1 graphs the average political finance index score globally, and in each region, from 1900 to 2012 . In $1960,98 \%$ of countries in the dataset did not have any subsidy law and by 1970 only $5 \%$ of countries had a law on the books. By 1980,11\% of countries at least had a law on the books and by 1990, the number had more than doubled to 23\%. The drop in Europe's average around 1990 corresponds to the former USSR countries gaining independence; by 2000, most of these countries had added some political finance regulations and the regional mean recovers.

Figure 1: Average political finance index score, by region 1900-2012

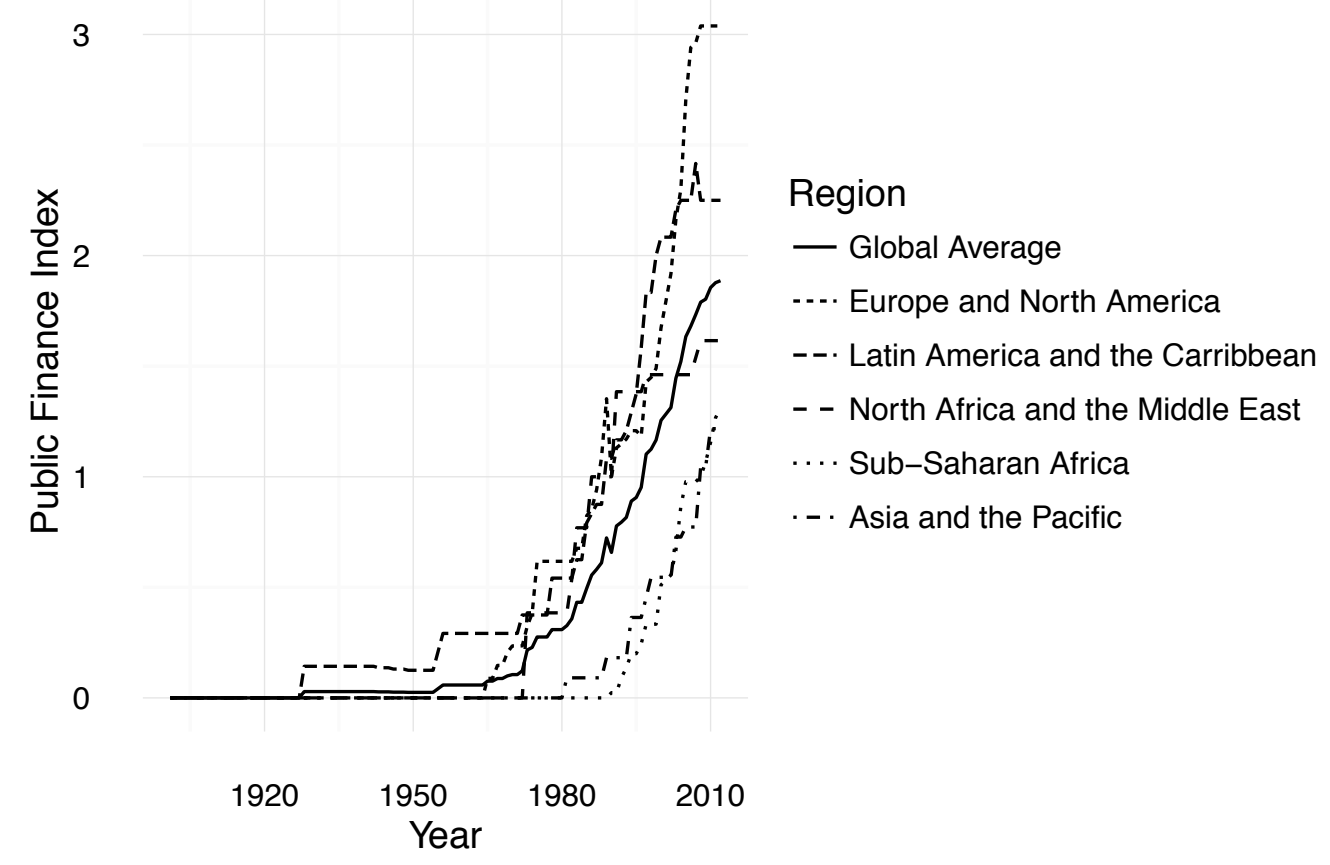

Graph of political finance index, aggregated by region and globally, 1900-2012.

In the $21^{\text {st }}$ century, political finance emerged as a global norm. By $2010,63 \%$ of countries in the dataset had a law on the books establishing subsidies and most distributed subsidies. In $20 \%$ of countries, public funds supplied the majority of the money in politics. Although political finance regulations are common in all regions, Europe has overtaken Latin America as the region with the most far-reaching legislation, while Africa and Asia lag behind. 


\subsection{A Time-Series Cross-Sectional Analysis of Political Finance Regimes}

To test the relationship between political finance and corruption we need to think carefully about the functional form of this relationship. We presume that the impact of political finance reform accrues over time but with diminishing marginal returns. To operationalize this expectation we construct a stock variable that adds the score registered for a country in each year (starting from 1900 up to the last year in our dataset, 2012) with a one percent depreciation rate (following Gerring et al. 2005). We further presume that the impact of a country's accumulated stock has diminishing marginal returns on corruption. The stock variable is therefore transformed by the natural logarithm.

To measure corruption, we rely on a measure drawn from the Varieties of Democracy dataset (McMann et al 2017). This corruption index aggregates indicators of corruption in different arenas - executive, legislative, public sector, and judicial. Underlying data is coded by country experts and integrated into a global dataset with a Bayesian latent variable measurement model (Pemstein et al. 2015). McMann et al (2017) report that the V-Dem index covers more types of corruption than other corruption datasets and aligns with theoretical definitions of corruption. They also find that the individual indicators load heavily on a single dimension, justifying the construction of an aggregated index (McMann et al 2017, p.9-12).

We recognize that all corruption indices are prone to measurement error (Jensen et al 2010; Olken \& Pande 2012; Sequeira \& Djankov 2010). There is no way of knowing exactly how much corruption exists because individuals have incentives to hide or underreport the corruption that they engage in, and may be unaware of what goes on outside their immediate purview (Della Porta \& Vannucci 1999; Olken 2009). Nonetheless, these indices provide our best guess about the level of corruption obtaining in different countries around the world, and there is no reason to suspect that they are subject to systematic error with respect to the predictors of interest in this study.

The V-Dem index offers a substantial improvement in coverage relative to other indices, as yearly estimates extend from the turn of the twentieth century to the present, offering an unparalleled time series. Other cross-national measures, like Transparency International's Perceptions of Corruption index or the World Bank's corruption estimates, cover only the last two decades - during which time few countries have experienced appreciable change in their measured level of corruption. Note also that systematic error is most likely to be associated with cross-country comparisons, insofar as corruption may be understood or manifested differently in 
different contexts, rendering estimates that are not crossnationally equivalent. The expansive data provided by V-Dem allows for a time-series format (with country fixed-effects), where a country is compared to itself over time. This sort of comparison seems less prone to systematic error in measurement that might lead to biased estimates.

Table 1 summarizes descriptive statistics for each variable in the models in Table 2.

Table 1: Descriptive statistics

\begin{tabular}{lcccc|}
\hline & Minimum & Maximum & Mean & $\begin{array}{c}\text { Standard } \\
\text { Deviation }\end{array}$ \\
\hline Corruption Index (V-Dem) & .009 & .946 & .439 & .264 \\
PFI stock (ln) (authors & 0 & 5.594 & .601 & 1.344 \\
PFI stock (V-Dem) & -138.375 & 150.893 & -34.205 & 43.308 \\
Polyarchy & .008 & .958 & .321 & .281 \\
GDP per capita (log) & 5.315 & 10.667 & 7.844 & 1.037 \\
Urbanization & 008 & 1 & .350 & .250 \\
GDP Growth & -61.493 & 86.946 & 1.871 & 6.378 \\
Regular Elections (binary) & $0(39 \%)$ & $1(61 \%)$ & & \\
\hline
\end{tabular}

\subsection{Initial Tests}

Table 2 presents a series of time-series cross-sectional analyses where corruption is regressed against a political finance index (PFI). An ordinary least squares estimator is employed along with country and year fixed effects, with errors clustered by country. Right side variables are lagged five years behind the outcome.

Model 1 includes only the variable of theoretical interest, PFI stock (log). Model 2 adds several covariates commonly regarded as causes of corruption - and, perhaps, of political finance reform. A number of studies have shown that democracy has nonlinear effects on corruption (Treisman 2001, 2007; Rose-Ackerman 1999) and perhaps on policy implementation, including political finance (Norris \& Abel van Es 2016; Rose-Ackerman 1999). We therefore include an index measuring the quality of democracy - Polyarchy (Teorell et al. 2016) - and its quadratic. Virtually all studies of corruption regard economic development, measured as per capita GDP (log), as a background factor (Mauro 1995, Treisman 2001, 2007). Owing to the ubiquity of these variables in studies of corruption, and their strong performance in our models, we regard this as a benchmark model. 
In Model 3, we add several additional covariates that are less central in the literature but may nonetheless serve as confounders. This includes urban population, GDP growth, and regular elections (Fisman \& Svenson 2007, Mauro 1995, Treisman 2007). Results are significant and fairly stable across all model specifications where PFI is the predictor.

In Model 4, we adopt an alternate measure of political finance, drawn from V-Dem, where coding is by multiple country experts, aggregated together in a latent-variable measurement model. This variable is also calculated as historical stock. ${ }^{3}$ It is not logged because the V-Dem measurement model ensures that the underlying data approximate a normal distribution. Estimates show a somewhat weaker, but nonetheless negative and significant (at $\mathrm{p}<0.01)$, correlation between political finance and corruption. This provides some assurance that our results are not the product of measurement error for the treatment variable.

Table 2: Political finance and corruption 1900-2012

\begin{tabular}{|c|c|c|c|c|}
\hline & 1 & 2 & 3 & 4 \\
\hline PFI stock (ln) (authors) & $\begin{array}{c}-.034 * * * * \\
(.007)\end{array}$ & $\begin{array}{c}-.017 * * * \\
(.006)\end{array}$ & $\begin{array}{c}-.017 * * * \\
(.006)\end{array}$ & \\
\hline PFI stock (V-Dem) & & & & $\begin{array}{c}-.001 * * \\
(.0002)\end{array}$ \\
\hline Polyarchy & & $\begin{array}{l}.195^{*} \\
(.113)\end{array}$ & $\begin{array}{l}.248^{*} \\
(.149)\end{array}$ & $\begin{array}{c}.298^{* * *} \\
(.108)\end{array}$ \\
\hline Polyarchy $^{2}$ & & $\begin{array}{c}-.395^{* * * * *} \\
(.121)\end{array}$ & $\begin{array}{c}-.441 * * * \\
(.151)\end{array}$ & $\begin{array}{c}-.500^{* * * *} \\
(.108)\end{array}$ \\
\hline GDP per capita (log) & & $\begin{array}{l}-.05^{* *} \\
(.020)\end{array}$ & $\begin{array}{c}-.043^{* *} \\
(.020)\end{array}$ & $\begin{array}{c}-.052^{* * * *} \\
(.010)\end{array}$ \\
\hline Urbanization & & & $\begin{array}{l}-.192^{*} \\
(.020)\end{array}$ & \\
\hline GDP Growth & & & $\begin{array}{l}-.001 \\
(.002)\end{array}$ & \\
\hline Regular Elections & & & $\begin{array}{c}.011 \\
(.016)\end{array}$ & \\
\hline Year fixed effects & $\checkmark$ & $\checkmark$ & $\checkmark$ & $\checkmark$ \\
\hline Country fixed effects & $\checkmark$ & $\checkmark$ & $\checkmark$ & $\checkmark$ \\
\hline Countries & 154 & 141 & 137 & 152 \\
\hline Years & 111 & 111 & 111 & 111 \\
\hline Obs & 10,742 & 8,785 & 8,513 & 9,968 \\
\hline $\mathrm{R} 2$ (within) & $(0.13)$ & $(0.20)$ & $(0.21)$ & $(0.21)$ \\
\hline
\end{tabular}

Outcome: political corruption (V-Dem), forward-lagged by five years. Estimator: ordinary least squares panel analysis with two-way fixed effects (unit and time) and standard errors clustered by country. $* \leq \mathrm{p} .1 * * \mathrm{p} \leq .05 * * * \mathrm{p} \leq .01 * * * * \leq \mathrm{p} .001$

\footnotetext{
${ }^{3}$ The correlation between our measure and the V-Dem measure is .33.
} 
Figure 2 displays how predicted values for corruption vary with PFI stock (log) in Model 2, the benchmark model, holding all other variables at their means. Note that the confidence intervals increase at higher values of the PFI because there are few countries that have had comprehensive political finance regimes in place for more than 30 years. To gain a more specific understanding of this relationship, let us consider the hypothetical case of a country with no prior political finance experience $(\mathrm{PFI}=0)$ that adopts a full set of measures (a maximum score on the index) in year 1 and maintains those regulations over the subsequent decade (PFI=4.02). Levels of corruption in this country are predicted to fall from 0.49 to 0.42 or .37 standard deviations, which is equivalent to a shift in levels of corruption found in Cambodia to those found in Jordan.

\section{Figure 2: Predicted Values}

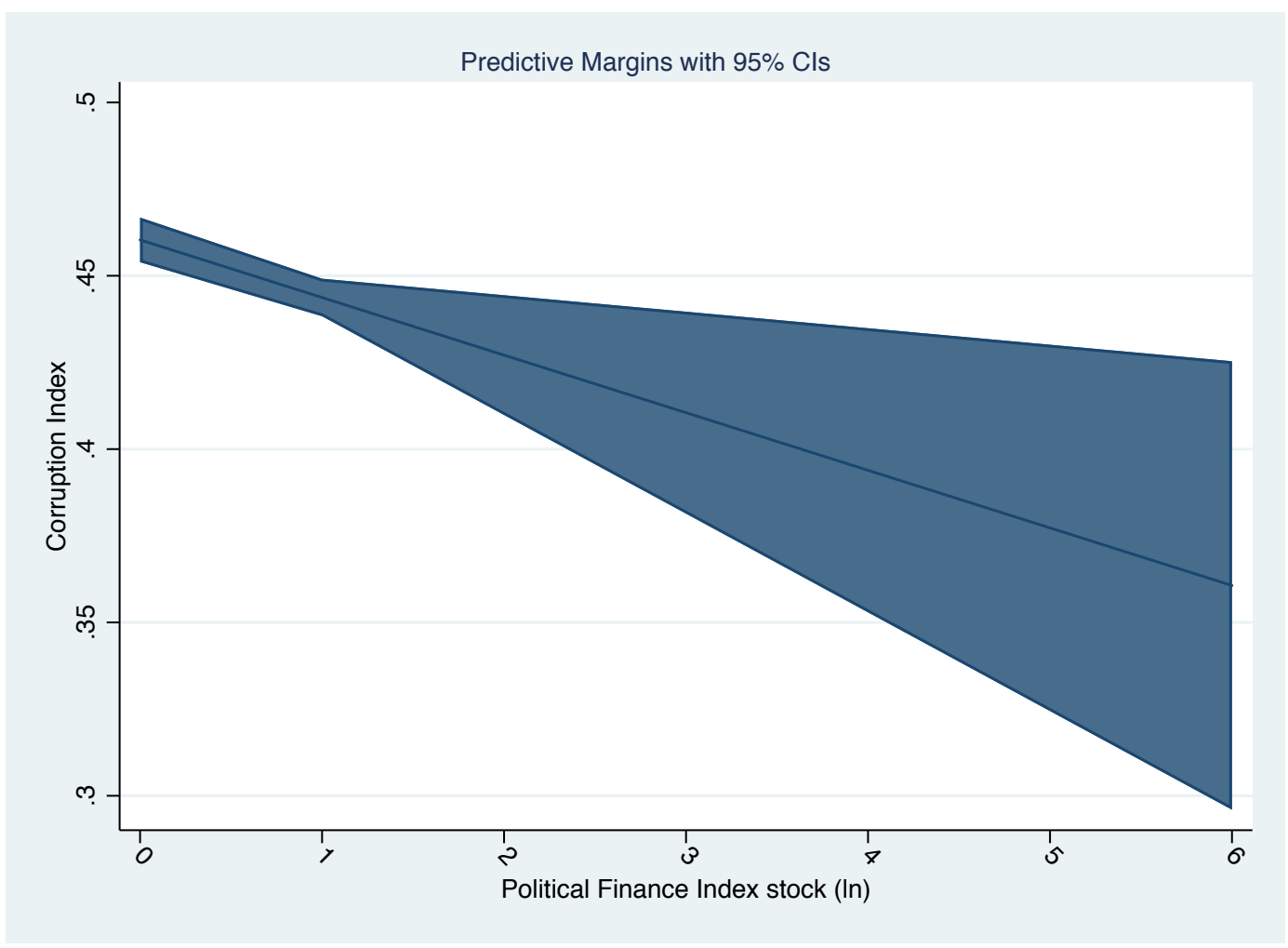

Predicted values for corruption as the PFI stock $(\log )$ increases, holding all other variables in the benchmark model at their means.

\subsection{Disaggregated Tests}

Corruption may exhibit itself in many ways and this gives us an additional point of leverage into the impact of political finance reform on political behavior. In Table 3, the corruption index is 
disaggregated into its component parts - measuring corruption in the executive, the legislature, the public sector, and the judiciary, respectively. Each forms a dependent variable in subsequent regression tests that mirror our benchmark model (Model 2, Table 2). Results are consistently negative and significant across all components, suggesting that political finance reform has wideranging effects across national-level institutions.

Table 3: Political finance and disaggregated corruption measures 1900-2012

\begin{tabular}{|c|c|c|c|c|c|}
\hline Outcome & $\begin{array}{l}\text { Executive } \\
\text { corruption }\end{array}$ & $\begin{array}{l}\text { Legislative } \\
\text { corruption }\end{array}$ & $\begin{array}{c}\text { Public } \\
\text { sector } \\
\text { corruption }\end{array}$ & $\begin{array}{l}\text { Judicial } \\
\text { corruption }\end{array}$ & $\begin{array}{c}\text { Media } \\
\text { corruption } \\
\text { (placebo) }\end{array}$ \\
\hline & 1 & 2 & 3 & 4 & 5 \\
\hline PFI stock (ln) & $\begin{array}{c}-.016^{* *} \\
(.008)\end{array}$ & $\begin{array}{c}-.079 * * \\
(.037)\end{array}$ & $\begin{array}{c}-.020 * * * \\
(.007)\end{array}$ & $\begin{array}{c}-.071 * * * \\
(.025)\end{array}$ & $\begin{array}{l}.033 \\
(.030)\end{array}$ \\
\hline Polyarchy & $\begin{array}{l}.038 \\
(.133)\end{array}$ & $\begin{array}{l}1.71 * * \\
(.823)\end{array}$ & $\begin{array}{l}.132 \\
(.118)\end{array}$ & $\begin{array}{c}.724 \\
(.479)\end{array}$ & $\begin{array}{c}-3.667 * * * * * \\
(.652)\end{array}$ \\
\hline Polyarchy $^{2}$ & $\begin{array}{c}-.276^{* *} \\
(.138)\end{array}$ & $\begin{array}{c}-2.271 * * * \\
(.829)\end{array}$ & $\begin{array}{c}-.338^{* * *} \\
(.121)\end{array}$ & $\begin{array}{c}-1.585^{* * *} \\
(.508)\end{array}$ & $\begin{array}{c}1.435^{* *} \\
(.700)\end{array}$ \\
\hline GDP per capita (logged) & $\begin{array}{c}-.049 * \\
(.027)\end{array}$ & $\begin{array}{c}-.241 * \\
(.135)\end{array}$ & $\begin{array}{c}-.041 * \\
(.021)\end{array}$ & $\begin{array}{c}-.224 * * * \\
(.081)\end{array}$ & $\begin{array}{l}-.107 \\
(.112)\end{array}$ \\
\hline Year fixed effects & $\checkmark$ & $\checkmark$ & $\checkmark$ & $\checkmark$ & $\checkmark$ \\
\hline Country fixed effects & $\checkmark$ & $\checkmark$ & $\checkmark$ & $\checkmark$ & $\checkmark$ \\
\hline Countries & 141 & 141 & 141 & 141 & 141 \\
\hline Years & 111 & 111 & 111 & 111 & 111 \\
\hline Obs & 8,785 & 8,785 & 8,785 & 8,785 & 8,785 \\
\hline $\mathrm{R} 2$ (within) & $(0.13)$ & $(0.16)$ & $(.0 .14)$ & $(0.18)$ & $(0.44)$ \\
\hline
\end{tabular}

Outcome: corruption in different sectors (V-Dem), forward-lagged by five years. Estimator: ordinary least squares panel analysis with two-way fixed effects (unit and time) and standard errors clustered by country. $* \leq \mathrm{p} .1 * * \mathrm{p} \leq .05 * * * \mathrm{p} \leq .01 * * * * \leq \mathrm{p} .001$

The final column of Table 3 adopts a slightly different outcome, measuring corruption in the media. This variable, also drawn from the V-Dem project, is not included as a component of the public corruption index. It measures the likelihood that members of the media take money or receive favors in exchange for altering their coverage of political events. Media corruption can be damaging to a polity, but is not strictly speaking public corruption since members of the media do not (generally) work for the government. Thus, we have no reason to suspect that changes in political finance would have any effect on levels of media corruption. Indeed, there is no relationship between the two factors in our benchmark specification, as shown in Model 5. 
We regard this as an important placebo test. If the covariation between PFI and public corruption were spurious, we would expect it to have a (spurious) relationship to other variables in the V-Dem dataset that measure similar outcomes.

Further robustness tests are contained in Appendix C. There, we explore changes in model specification, estimator, and sample, e.g., random effects (rather than fixed effects), lagged dependent variable models, varying lags of the right-side variables, and split-sample tests that restrict the sample to recent decades or drop influential cases or regions. We also show results for PFI in the benchmark model when varying depreciation rates are used in constructing the stock for this index, when the components of the PFI are aggregated using the first component of a principal components analysis, when the PFI is measured as a level (rather than stock) variable, and when the stock variable is measured in a linear, rather than logarithmic, form. In all these tests, political finance regulations show a strong, negative, and statistically significant relationship to political corruption.

\section{Case Study: Paraguay}

In this section of the paper, we develop a case study to illustrate the argument and to shed light on the mechanisms $(M)$ that may lie between the apparent cause, $X$ (political finance reform), and the outcome, $Y$ (corruption). To serve this "pathway" function we searched for a case that seems to exhibit the relationship of interest - as portrayed in the cross-country empirical analysis - without a lot of potential confounders $(Z)$. Assuming for the moment that $X$ causes $Y$ across the population, the pathway case is a country where $X$ covaries with $Y$ and $Z$ is constant or exhibits a trend that is inconsistent with observed variation in $Y$ (Gerring 2017).

Beginning with our global sample, we began by eliminating cases with little or no variation in $X$. Second, we eliminated rich countries, where improvements in corruption might be the product of modernization. (In the aggregate, i.e., in the panel analysis, we are confident that aggregate modernization effects are effectively handled through covariates measuring per capita GDP, GDP growth, and urbanization. At the case level, stochastic features pose a greater threat.) Third, we ran bivariate time-series analyses for the remaining countries to see where there was a strongly negative relationship between political finance subsidies and corruption, thus offering a possibility of elucidating the causal pathway of theoretical interest. A small sample of countries passed this remaining test. Looking closely at the details of these cases, we determined that Paraguay was least subject to potential confounders (other events coincident in time with political finance reform), and therefore an appropriate choice for intensive analysis. 
While many countries legislate political finance subsidies as part of a large reform package or a constitutional reform during a regime change, Paraguay introduced its political finance reform several years after a new constitution and transition to democracy.

To develop the case study, one coauthor spent three months in Asunción, Paraguay, conducting elite interviews. Informants included top political figures who were active when the 1996 reform was debated and adopted, currently active officials, and NGO workers and academics who focus on political finance and corruption issues. We use the full names of elected officials who spoke with us on record because they are public figures, and thus do not require confidentiality according to IRB guidelines. The names of other informants - appointed officials, political operatives, NGO workers, and academics - have been replaced with pseudonyms in accordance with IRB guidelines. A protocol of questions, a list of interview dates and names (for elected officials whose anonymity is not protected), is contained in Appendix D.

\subsection{Background}

Paraguay experienced institutionalized corruption under the Stroessner dictatorship, from 1954 to 1989. During the authoritarian era, General Stroessner and his Colorado party controlled the state and encouraged corruption as a way to pad salaries (Nickson 1997, p.24). High-level officials were also involved in drug trafficking (Nickson \& Lambert 2002, p.166). Though corruption has declined in recent decades, Paraguay remains the fifth most corrupt country in Latin America, according to the V-Dem corruption index. Former president Federico Franco states, "Paraguay is known for its triple border, narco-trafficking, car trafficking, wood smuggling, all sorts of illegal money." "Bribery is often expected from public officials, embezzlement is commonplace, and few corruption cases make it through the courts (Hetherington 2011, Lambert \& Nickson 2002, p.166). Figure 3 illustrates Paraguay's decline from extreme corruption during the Stroessner dictatorship to moderate corruption under the current regime.

\footnotetext{
${ }^{4}$ Interview with Federico Franco, July 3, 2017
} 
Figure 3. Corruption in Paraguay, 1900-2012

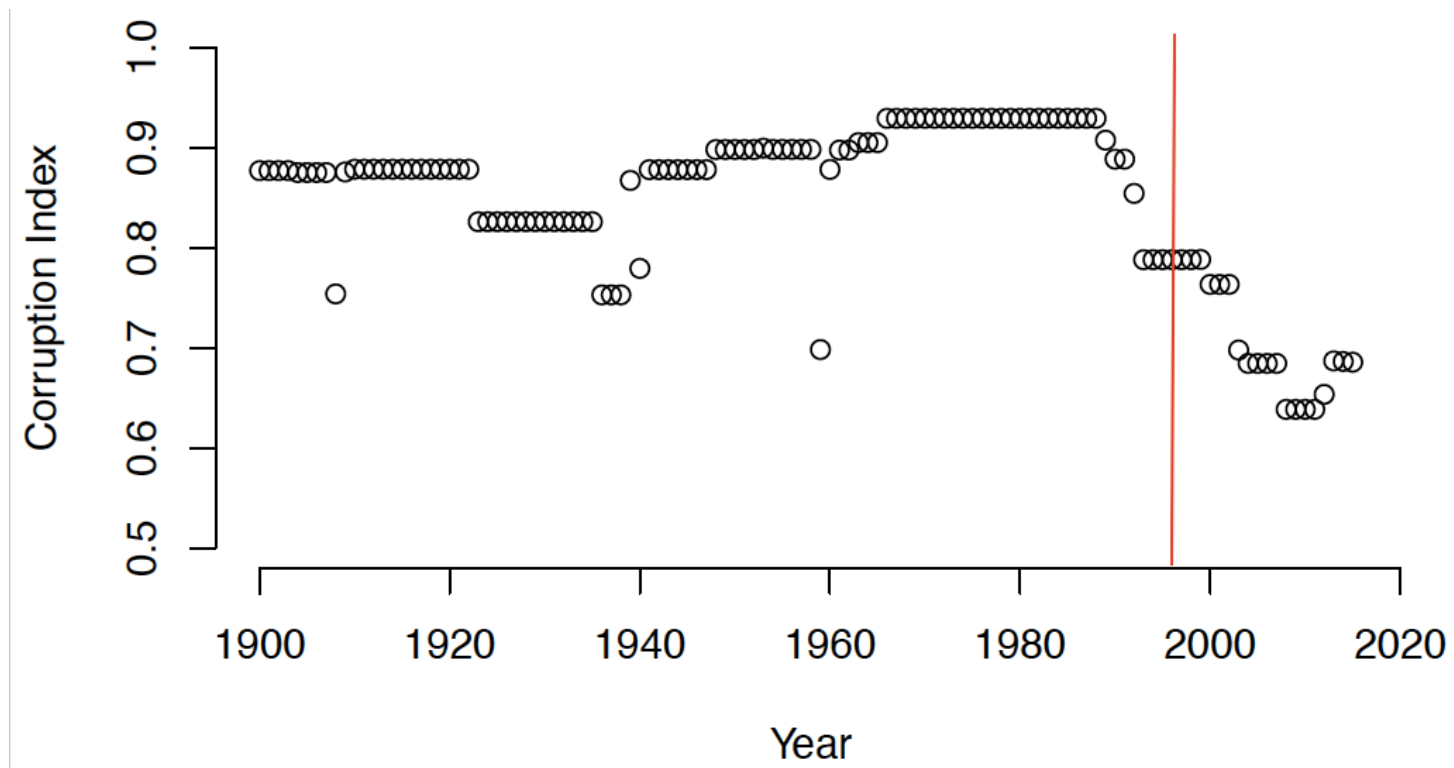

The vertical line marks the initiation of political finance reform (1996).

Granted, some of that improvement might be credited to the transition to democracy, as suggested by the time-series in Figure 3. Following a coup that returned the country to civilian rule, Paraguay introduced a new constitution (1992), and held its first democratic elections (1993). However, the transition to democracy cannot plausibly account for all the progress that Paraguay has registered in combatting corruption. Note that democratic transitions are usually accompanied by an increase in corruption - especially electoral corruption, insofar as parties and politicians now must compete in multi-party elections, and often choose to do so with an expenditure of funds to buy votes or influence turnout, among other things (Keefer 2007; McMann et al. 2017). We see considerable evidence of this in the Paraguayan case, vindicating the widely accepted view that the first-order effects of democratization on corruption are negative rather than positive. In the 1993 election, the Colorados were the only party with a developed party infrastructure and experienced personnel, as well as unrestricted access to state resources (Riquelme \& Riquelme 1997, p.48). In an election marked by rampant vote buying and embezzlement where campaigns were run out of state offices, the Colorados easily beat the disorganized and underfunded Liberal opposition party (ibid).

Colorado politicians, in consultation with Liberal representatives, introduced political finance legislation. Both parties wanted legitimate state funds for their campaigns and party organizations. Additionally, the Colorados were confident that they could maintain their national majority against a better-funded opposition, particularly since subsidies are allocated based on how many seats each party has in Congress, an arrangement that continues to favor the 
Colorados. The law explicitly outlawed the use of state resources and facilities for campaigns and required parties to publish financial accounts. The law also introduced substantial subsidies for campaigns and yearly subsidies for parties, and public subsidies now cover roughly half of a campaign's expenses, though the proportion of public to private money is dropping. The two larger parties fund day-to-day operations with a mix of private and public money, but smaller parties rely almost entirely on public funding. In 1996, 18 newly appointed electoral judges were charged with enforcing the law, which only uses injunctions and confiscation to punish violations.

In interviews, officials from multiple parties stated that Colorado politicians proposed the law as a limited concession to the Liberal party and as a strategy for creating a stable, legal funding base for both parties. The law enjoyed bipartisan support from Colorados and Liberals. Most Liberals supported the subsidies because they provided a basic level of guaranteed funding that, they assumed, would enable the party to compete more successfully. However, some Liberals and third parties criticized the agreement because disbursements are based on how many seats a party has in the legislature, sending a majority of funds to the Colorados. Colorados supported the plan because it handed them guaranteed and legal funding, and made elections more competitive without threatening their hold on the executive or legislative majorities. Subsidies were first distributed to parties in 1997 and to candidates in the 1998 elections. Subsidies appear to have had an immediate electoral effect, even with this uneven distribution across the two major parties. With a guaranteed funding floor, Liberal politicians were able to run viable campaigns and won additional seats in the 1998 elections, especially at local levels. Still, the Colorados maintained their legislative majority and have held the executive in all but one election.

\subsection{Effects and Mechanisms}

We turn now to the question of theoretical interest. Did the passage of campaign finance reform reduce corruption in Paraguay? Our interview data strongly suggest that it did. To explain the relationship, interviewees pointed to several causal mechanisms.

First, public funding displaced the importance of private money in campaigns and gave officials more discretion over funding sources. Carlos Riveros, a former Liberal Party congressman who was in office during the 1996 reform, explained, "This public subsidy to the parties plays a very important role. It is the foundation of its finances, but it isn't everything... In terms of incentives for corruption, when one has resources they don't need to resort to 
extremes, and can use these resources." ${ }^{55}$ Riveros implies that politicians will resort to corruption to fund organizations and campaigns, but that they see corruption as an extreme option and would prefer legal sources. A community organizer for the Liberal Party agreed: "The greater the influx of state subsidies, the greater the diminishing of the need to resort to other types of financing." "Sebastian Acha, a former senator from the small Patria Querida party added, "Public funds allow honest politicians to compete." These statements are consistent with our argument, which posits that public subsidies reduce the role of private money in politics and in doing so, reduce incentives for corruption.

Second, the law clarified what was legal and illegal in political financing and introduced minimal accountability regulations. These measures standardized practices and expectations around political finance. Prior to the law, few politicians kept records of expenditures and officials ran campaigns out of state offices. Under the circumstances, it was hard for the press, or the public - or even the politicians - to tell when they were on the right side of the law. After the passage of the law, officials knew that they were expected to keep records of where money came from and how it was spent, and they knew that the law outlawed the use of state resources for campaigns and party activities. Thus, the behavior of politicians could be judged, and by virtue of being clear was more likely to be followed - a good instance of statutes paving the way for behavioral change.

Third, the law inaugurated an enforcement regime. Judge Raúl Gonzalez Ruiz, the first electoral judge in Asunción tasked with enforcing the law, remembers that when he first started enforcing the law, embezzlement and the misuse of state resources were endemic. In our data, Paraguay's corruption score stood at .788 in 1996, far above the global average of .531 that year. Candidates routinely held campaign events in public buildings and used public resources, and Ruiz recalls evicting a band playing the Colorado Party polka from the Ministry of Public Works. ${ }^{7}$ The judge impounded nearly 100 official vehicles and a goat in the first municipal campaign cycle after the law passed.

Fourth, the media took up the trumpet of anti-corruption, amplifying messages emanating from the judiciary. Indeed, officials charged with enforcing political finance regulations actively worked with the media to shame violators, and the media made extensive use of the law. Ruiz invited journalists to come with him to deliver injunctions, "The largest fear was exposure to the media. This generated intense fear in public servants... we always tried to take

\footnotetext{
${ }^{5}$ Interview with Carlos Riveros, July 19th, 2017.

${ }^{6}$ Interview with Alejandro Armendia, July 20th 2017.

${ }^{7}$ Interview with Raúl Gonzalez Ruiz, July 17th, 2017.
} 
the media with us when we intervened." "Former president Franco agrees that the media has helped enforce the law and its sanctions, "[Politicians] fear that a citizen or journalist might expose them... The media and social media served to make this law applicable." ${ }^{9}$ Thus, Paraguay's experience suggests that in the absence of strong legal sanctions, social sanctions can help the anti-corruption features of a political finance reform take effect. This is the case even in Paraguay, which has a weak civil society, one of the lowest levels of political participation in Latin America, and few NGOs following political finance policy (Hetherington 2011, Nickson \& Lambert 1997).

Finally, politicians and observers report that voters punish officials caught engaging in political finance-related corruption. Voters know that parties and campaigns receive public subsidies and they know that officials cannot use state resources for partisan activities. They denounce corruption to the media and appear to punish blatantly corrupt officials at the polls. Acha claims, "There has been little judicial consequence for cheating the system by the government, but a social consequence has been at play in punishing politicians who sell out. Voters don't tolerate using public party funds and then proving disloyal." ${ }^{10}$ Media monitoring of compliance with the 1996 law and voter punishment for those who violate it appear to reduce corruption, even where official audits and sanctions are rare. Thus, even with weak sanctions and uneven implementation, Paraguay's campaign and party organization subsidies appear to have reduced corruption.

Though we cannot say which of these five mechanisms was most important, it seems plausible that they all played a role in reducing endemic levels of corruption in Paraguay over the past several decades - an improvement registered in Figure 3 and supported by our interviewees. By all accounts, embezzlement and misuse declined precipitously after Ruiz and a handful of other electoral judges intermittently applied the law's minimal punishments. Between the 1998 general election and the 2003 general election, Paraguay's corruption score dropped from .788 to .769, a notable improvement for a country with persistently high corruption. Now, a party official states, “The open use of state resources has diminished greatly. You won't see people using state vehicles or taking cold hard cash from the state in order to fund a campaign." ${ }^{\text {"11 }}$ Ruiz adds:

In the first years of the 1996 law, the open proselytism in public offices mostly disappeared. It did waver throughout time, in accordance to how strict

\footnotetext{
${ }^{8}$ Interview with Raúl Gonzalez Ruiz, July 17th, 2017.

${ }_{9}^{9}$ Interview with Federico Franco, July 3, 2017.

${ }^{10}$ Interview with Sebastian Acha, June 27th, 2017.

${ }^{11}$ Interview with Cachito Mendoza, July 19 ${ }^{\text {th }}, 2017$
} 
electoral judges were at a given time, but there are certain things that just don't happen anymore. You won't find a political poster in a public office nowadays. I think there is still covert use of public goods in some areas. It is still done, but undercover, with numerous precautions. As a political practice, it has largely lost force.

Riveros speculates that, "Without this subsidy, corruption would have perhaps been more widespread, although the use of dirty money is still in play in our country." ${ }^{12}$ While Paraguay's public subsidies reduced corruption by reducing the role of private money and increasing sanctions for corruption, political expenditures have grown much faster than subsidies in the last decade. As private money again becomes more important in Paraguayan campaigns, corruption has inched back up. Acha explains that, "As the cost of campaigns has risen, the positive effect has been reduced, as the amount of public financing represents less than $50 \%$ of total campaign costs, and now competes with private money of dubious origin."13 Still, even with more illicit money in campaigns, observers state that embezzlement and the misuse of state resources have not increased. Overall, Acha claims that the 1996 law reversed a trend towards more and insidious forms of corruption, "The 1996 law has generally prevented this country from turning into a narcocracy, or a kleptocracy." 14

\section{Conclusion}

Every year, governments around the world disburse billions of public dollars to political parties and campaigns. Political finance reform has vocal proponents and critics among voters, researchers, and policymakers. Proponents claim that political finance regulations and subsidies reduce public corruption, reign in special interests, and broaden representation. Critics claim that subsidies channel public money to corrupt politicians and organizations, benefit established parties to the detriment of new or small ones, and waste public money. Despite these established debates, few studies have evaluated the effects of political finance laws.

This project uses an original dataset of political party and campaign subsidies in 154 countries over 112 years to evaluate claims about political finance laws and corruption. We argue that subsidies for parties and campaigns reduce corruption by curtailing the role of private money in politics and increasing sanctions for corrupt politicians. With more discretion over where funds come from and under the threat of more serious sanctions for malfeasance, officials

\footnotetext{
12 Interview with Carlos Riveros, July 19th, 2017

13 Interview with Sebastian Acha, June 27th, 2017

${ }^{14}$ Interview with Sebastian Acha, June 27th 2017.
} 
prioritize clean money over suspect funds. As a result, subsidies reduce corruption by displacing bribes and embezzlement, and accompanying campaign finance regulation increases the legal and social sanctions for being caught.

Our crossnational panel analysis finds that political finance reform is negatively associated with political corruption. The relationship remains stable after adjusting for time and country effects, and controlling for the quality of democracy, GDP per capita, GDP growth, population, and regular elections - along with a series of additional robustness tests carried out in Appendix C. An intensive case study focused on Paraguay's 1996 political finance reform illustrates the process and the theoretical mechanisms behind the quantitative results: after the 1996 reform, public corruption, particularly embezzlement and the misuse of state resources, decreased even in the face of uneven implementation. Officials attribute the decrease, in part, to political finance regulations.

This study contributes to debates on political finance by establishing a strong case for the role of political finance in reducing corruption - even in highly corrupt, poorly institutionalized political contexts. Indeed, the experience of Paraguay suggests that reforms may have the greatest impact where corruption is most widespread. In future research, we hope to be able to disentangle the effects of political subsidies and regulations - here understood as part of an omnibus treatment. 


\section{References}

Abramowitz, Alan I. 1988. "Explaining Senate election outcomes." American Political Science Review 82.2: 385-403.

Alexander, Herbert E \& Rei Shiratori, eds. 1994. Comparative political finance among the democracies. Westview Press.

Americas' Accountability Anti-Corruption Project. 2004. Political-Party Finance in Argentina, Chile, Costa Rica and Mexico: Lessons for Latin America. Retrieved from http://pdf.usaid.gov/pdf docs/Pnada553.pdf

Avkiran, Necmi K., Direnç K. Kanol, and Barry Oliver. 2016. "Knowledge of campaign finance regulation reduces perceptions of corruption." Accounting \& Finance 56.4: 961-984.

Balán, Manuel. 2011. "Competition by denunciation: The political dynamics of corruption scandals in Argentina and Chile." Comparative Politics 459-478.

Bardhan, Pranab. 2006. "The economist's approach to the problem of corruption." World Development 34 (2): 341-348.

Basinger, Scott J. 2013. "Scandals and congressional elections in the post-Watergate era." Political Research Quarterly 66.2: 385-398.

Briffault. Richard. 2016. "South Africa." In Norris, Pippa, and Andrea Abel van Es, Eds. Checkbook. Elections?: Political Finance in Comparative Perspective. Oxford University Press.

Bryan, Shari, Denise Baer (eds.). 2005. Money in Politics - A study of Party Financing Practices in 22 countries. NDI.

Beauchamp, Zack. 2016. "Brazil's Petrobras scandal, explained." Vox, URL http://www. vox.com/2016/3/18/11260924/petrobras-brazil.

Berliner, Daniel and Aaron Erlich. 2015. "Competing for transparency: Political competition and institutional reform in Mexican states." American Political Science Review 109(01): 110-128.

Calland, Richard. 2016. "South Africa." In Norris, Pippa, and Andrea Abel van Es, Eds. Checkbook Elections?: Political Finance in Comparative Perspective. Oxford University Press.

Carlson, Matthew. 2016. "Japan.” In Norris, Pippa, and Andrea Abel van Es, Eds. Checkbook Elections?: Political Finance in Comparative Perspective. Oxford University Press.

Casas-Zamora, Kevin. 2005. Paying for democracy: political finance and state funding for parties. ECPR Press.

Coppedge, Michael, John Gerring, Staffan I. Lindberg, Svend-Erik Skaaning, Jan Teorell, David Altman, Michael Bernhard, M. Steven Fish, Adam Glynn, Allen Hicken, Carl Henrik Knutsen, Kyle L. Marquardt, Kelly McMann, Valeriya Mechkova, Pamela Paxton, Daniel Pemstein, Laura Saxer, Brigitte Seim, Rachel Sigman, and Jeffrey Staton. 2017. "V-Dem Codebook v7.1." Varieties of Democracy (V-Dem) Project 
Council of Europe. 2003. Recommendation Rec(2003)4 of the Committee of Ministers to member states on common rules against corruption in the funding of political parties and electoral campaigns. Retrieved from https://rm.coe.int/16806cc1f1.

Corbacho Ana, Daniel W. Gingerich, Virginia Oliveros, Mauricio Ruiz-Vega. 2016. "Corruption as a Self-Fulfilling Prophecy: Evidence from a Survey Experiment in Costa Rica." American Journal of Political Science 60:4, 1077-1092.

Della Porta, Donatella and Alberto Vannucci. 1999. Corrupt exchanges: Actors, resources, and mechanisms of political corruption. Piscataway, NJ: Transaction Publishers.

Evertsson, Nubia. 2013. "Political corruption and electoral funding: a cross-national analysis." International Criminal Justice Review 23.1: 75-94.

Ferraz, Claudio, and Frederico Finan. 2008. "Exposing corrupt politicians: the effects of Brazil's publicly released audits on electoral outcomes." The Quarterly Journal of Economics 123.2: 703-745.

Fisher, Justin. 2000. "Party Finance and Corruption: Britain.” In Williams, Robert (ed), Party finance and political corruption. Pages 15-36. Basingstoke: Macmillan Press.

Fisman, Raymond and Jakob Svensson. 2007. "Are corruption and taxation really harmful to growth? Firm level evidence.” Journal of Development Economics, 83(1): 63-75.

Gaventa, John and Rosemary McGee. 2013. "The impact of transparency and accountability initiatives.” Development Policy Review, 31(1): 3-28.

Gerber, Alan. 1998. "Estimating the effect of campaign spending on senate election outcomes using instrumental variables." American Political Science Review 92.2: 401-411.

Gerring, John. 2017. Case study research: Principles and practices, $2 d$ ed. Cambridge University Press.

Gerring, John, Philip Bond, William Barndt, Carola Moreno. 2005. "Democracy and Growth: A Historical Perspective." World Politics 57:3 (April) 323-64.

Gingerich, Daniel. 2009. "Corruption and political decay: Evidence from Bolivia." Quarterly Journal of Political Science, 4(1): 1-34.

Gokcekus, Omer, and Sertac Sonan. 2016. "Political contributions and corruption in the United States." Journal of Economic Policy Reform 1-13.

Green, Donald Philip, and Jonathan S. Krasno. 1988. "Salvation for the spendthrift incumbent: Reestimating the effects of campaign spending in House elections." American Journal of Political Science 884-907.

Hetherington, Kregg. 2011. Guerrilla Auditors: The Politics of Transparency in Neoliberal Paraguay. Durham, NC: Duke University Press.

Hopkin, Jonathan. 2004. "The problem with party finance: Theoretical perspectives on the funding of party politics." Party politics 10.6: 627-651.

Instituto de Investigaciones Jurídicas. 2011. Financiamiento de los Partidos Políticos en América Latina. Retrieved from https://www.oas.org/es/sap/docs/deco/financiamiento_partidos_s.pdf 
International Institute for Democracy and Electoral Assistance. 2017. Political Finance Database. Retrieved from http://www.idea.int/data-tools/data/political-finance-database.

International Institute for Democracy and Electoral Assistance. 2014. Funding of Political Parties and Election Campaigns: A Handbook on Political Finance. Stockholm: International Institute for Democracy and Electoral Assistance.

Jensen, Nathan M, Quan Li, and Aminur Rahman. 2010. "Understanding corruption and firm responses in cross-national firm-level surveys." Journal of International Business Studies, 41(9): 1481-1504.

Keefer, Philip. 2007. "Clientelism, Credibility, and the Policy Choices of Young Democracies." American Journal of Political Science 51:4, 804-821.

Kosack, Stephen and Archon Fung. 2014. "Does transparency improve governance?” Annual Review of Political Science, 17: 65-87.

Koß, Michael. 2010. The Politics of Party Funding: State Funding to Political Parties and Party Competition in Western Europe. Oxford: Oxford University Press.

La Raja, Raymond J. 2008. Small change: Money, political parties, and campaign finance reform. University of Michigan Press.

La Raja, Raymond J. 2014a. "Money in the 2014 Congressional Elections: Institutionalizing a Broken Regulatory System." The Forum. 12.4.

La Raja, Raymond J. 2014b. "Political Participation and Civic Courage: The Negative Effect of Transparency on Making Small Campaign Contributions." Political Behavior 36.4: 753-776.

Levitt, Steven D. 1994. "Using repeat challengers to estimate the effect of campaign spending on election outcomes in the US House." Journal of Political Economy 102.4: 777-798.

Mauro, Paolo. 1995. "Corruption and growth." The Quarterly Journal of Economics, 110(3): $681-712$.

McMann, Kelly, Brigitte Seim, Jan Teorell, and Staffan I. Lindberg. 2017. "Democracy and Corruption: A Global Time-Series Analysis with V-Dem Data." Varieties of Democracy Institute: Working Paper No. 43.

McMenamin, Iain. 2012. "If money talks, what does it say? Varieties of capitalism and business financing of parties." World Politics 64.1: 1-38.

McSweeney, Dean. 2000. "Parties, Corruption and Campaign Finance in America." In Robert Williams (ed), Party finance and political corruption. Pages 37-60. Basingstoke: Macmillan Press.

Mietzer, Marcus. 2016. "Indonesia." In Norris, Pippa, and Andrea Abel van Es, Eds. Checkbook Elections?: Political Finance in Comparative Perspective. Oxford University Press.

Norris, Pippa, and Andrea Abel van Es. 2016. Checkbook Elections?: Political Finance in Comparative Perspective. Oxford: Oxford University Press. 
Olken, Benjamin. 2009. "Corruption perceptions versus corruption reality." Journal of Public Economics, 93(7): 950-964.

Olken, Benjamin. 2010. "Direct democracy and local public goods: Evidence from a field experiment in Indonesia." American Political Science Review, 104(02): 243-267.

Olken, Benjamin A and Rohini Pande. 2012. "Corruption in developing countries." Annual Review of Economics, 4: 459-505.

Organization of American States. 2005. From the Grassroots to the Airwaves: Paying for Political Parties and Campaigns in the Carribean. Retrieved from https://www.oas.org/sap/docs/publications/grassroots.pdf

Pemstein, Daniel, Kyle L. Marquardt, Eitan Tzelgov, Yi-ting Wang, and Farhad Miri. 2015. "The V-Dem Measurement Model: Latent Variable Analysis for Cross-National and Cross-Temporal Expert-Coded Data." Varieties of Democracy Institute: Working Paper Series, No. 21.

Pinto-Duschinsky, Michael. 2002. "Financing politics: A global view." Journal of Democracy 13.4: 69-86.

Poguntke, Thomas, et al. 2016. "Party rules, party resources and the politics of parliamentary democracies: How parties organize in the 21st century." Party politics 22.6: 661-678.

Primo, David M., and Jeffrey Milyo. 2006. "Campaign finance laws and political efficacy: evidence from the states." Election Law Journal 5.1: 23-39.

Rix, Kathryn. 2008. "'The Elimination of Corrupt Practices in British Elections'? Reassessing the Impact of the 1883 Corrupt Practices Act." The English Historical Review 123.500: 65-97.

Roper, Steven D. 2002. "The influence of Romanian campaign finance laws on party system development and corruption." Party Politics 8.2: 175-192.

Rose-Ackerman, Susan. 1978. Corruption: A study in political economy. New York: Academic Press.

Rose-Ackerman, Susan. 1999. Corruption and government: Causes, consequences, and reform. Cambridge: Cambridge University Press.

Samuels, David. 2001. "Does money matter? Credible commitments and campaign finance in new democracies: theory and evidence from Brazil." Comparative Politics 23-42.

Scarrow, Susan E. 2004. "Explaining political finance reforms: competition and context." Party Politics 10.6: 653-675.

Scarrow, Susan E. 2007. "Political Finance in Comparative Perspective." Annual Review of Political Science, 10: 193-210.

Schneider, Benjamin. 2006. Business Politics and the State in twentieth-century Latin America. Cambridge: Cambridge University Press.

Seawright, Jason, and John Gerring. 2008. "Case selection techniques in case study research: A menu of qualitative and quantitative options." Political Research Quarterly 61.2: 294-308. 
Sequeira, Sandra and Simeon Djankov. 2014. "Corruption and firm behavior: Evidence from African ports.” Journal of International Economics, 94(2): 277-294.

Teorell, Jan, Michael Coppedge, Svend-Erik Skaaning, Staffan I. Lindberg. 2016.

"Measuring Electoral Democracy with V-Dem Data: Introducing a New Polyarchy Index." Varieties of Democracy working paper.

Transparency International. 2016. "Perceptions of Corruption Index." Retrieved from https://www.transparency.org/news/feature/corruption_perceptions_index_2016

Treisman, Daniel. 2000. "The causes of corruption: A cross-national study." Journal of Public Economics, 76(3): 399-457.

Treisman, Daniel. 2007. "What have we learned about the causes of corruption from ten years of cross- national empirical research?” Annual Review of Political Science, 10: 211-244.

Vaishnav, Milan. 2017. When crime pays: money and muscle in Indian politics. Yale University Press.

Williams, Robert (ed). 2000. Party finance and political corruption. Basingstoke: Macmillan Press.

World Bank. 2017. "World Bank Development Indicators.” Retrieved from http://databank.worldbank.org/data/reports.aspx?source=world-developmentindicators 